University of Nebraska - Lincoln

DigitalCommons@University of Nebraska - Lincoln

1970

\title{
Suppression and Elimination of an Island Population of Culex pipiens quinquefasciatus with Sterile Males
}

\author{
R. S. Patterson \\ ARS-USDA \\ D. E. Weidhaas \\ ARS-USDA \\ H. R. Ford \\ ARS-USDA \\ C. S. Lofgren \\ ARS-USDA
}

Follow this and additional works at: https://digitalcommons.unl.edu/entomologyother

Part of the Entomology Commons

Patterson, R. S.; Weidhaas, D. E.; Ford, H. R.; and Lofgren, C. S., "Suppression and Elimination of an Island Population of Culex pipiens quinquefasciatus with Sterile Males" (1970). Entomology Papers from Other Sources. 50.

https://digitalcommons.unl.edu/entomologyother/50

This Article is brought to you for free and open access by the Entomology Collections, Miscellaneous at DigitalCommons@University of Nebraska - Lincoln. It has been accepted for inclusion in Entomology Papers from Other Sources by an authorized administrator of DigitalCommons@University of Nebraska - Lincoln. 


\section{Suppression and Elimination of an Island Population of Culex pipiens quinquefasciatus with Sterile Males}

Abstract. The release of 8,400 to 18,000 males per day of Culex pipiens quinquefasciatus Say which had been exposed to a sterilizing agent (thiotepa), suppressed and eliminated an indigenous population of this mosquito on an island off the coast of Florida in a 10-week period. Sterile males were effective in seeking out and mating with females on the island.

Culex pipiens quinquefasciatus Say (=Culex fatigans Wiedemann) is a vector of human diseases, particularly filariasis, and can be controlled with insecticides. We now report that the technique of male sterilization can be used to suppress population build-ups of $C$. $p$. 1368 males were competitive with the wild males, and, when the test was discontinued after 8 weeks because of the onset of cool weather, 85 percent of the egg rafts collected were sterile (1).

We conducted a similar study in 1969 to show that sterile males could be used to suppress or eliminate an isolated population of C. p. quinquefasciatus. The test site was Seahorse Key, a crescent-shaped island, about 1.6 by 0.2 $\mathrm{km}$; it is covered by dense woods except for a large $T$-shaped clearing that extends across the center of the island.

The primary larval breeding site for C. p. quinquefasciatus was a partially open septic tank that received domestic wastes. Breeding also occurred in containers that had been discarded in the woods where they collected rainwater.

The mosquitoes were reared as larvae at the Insects Affecting Man and Animals Research Laboratory at Gainesville, Florida. We sterilized the mosquitoes in the pupal stage by exposing them for 4 hours to an aqueous solution of 0.75 percent thiotepa [tris(1aziridinyl) phosphine sulfide]. The mosquitoes were then placed on wet blotting paper in pans in Styrofoam boxes chilled with ice and transported to the release site. At Seahorse Key, the pans were placed under the laboratory, the lids were removed, and fresh water was added to float the remaining pupae. The sterile adults dispersed rapidly into the environment, and large numbers were seen in mating swarms at dusk and dawn throughout the cleared area of the island.

Egg rafts were collected from the indigenous population in 12 ovitraps (40liter tubs containing larval food) located at the edge of the woods and in open areas near the main breeding sites. The egg rafts were collected and counted daily and then placed in separate 18.5$\mathrm{ml}$ vials containing $5 \mathrm{ml}$ of water. Most fertile eggs hatched within 24 hours, but all eggs were kept for 4 days before they were determined to be viable or nonviable. Since the larvae from fertile egg rafts were destroyed, our assay procedures exerted an additional control on the mosquito population similar to what could be achieved with larvicides or removal of breeding sites.

Because fluctuations in egg production caused by varying weather conditions made the daily records difficult to interpret, we combined the data for each quinquefasciatus or to eliminate it from certain areas. We studied methods of sterilization and mass rearing and the biology of this species. In 1968 we released males, sterilized chemically with tepa, on Seahorse Key, located about 3.2 $\mathrm{km}$ off the west coast of Florida. These 
Table 1. Release, sterility, and control data for the sterile male release experiment with $C$. p. quinquefasciatus on Seahorse Key. Our ovitraps collected about 50 percent of the total number of egg rafts that were oviposited by females each day. These egg rafts were destroyed.

\begin{tabular}{|c|c|c|c|c|c|c|c|c|}
\hline \multicolumn{3}{|c|}{ Release data } & \multicolumn{4}{|c|}{ Egg raft data } & \multirow{2}{*}{\multicolumn{2}{|c|}{$\begin{array}{l}\text { Reduction in No. of } \\
\text { egg rafts collected } \\
(\%)\end{array}$}} \\
\hline \multirow{2}{*}{$\begin{array}{l}\text { Genera- } \\
\text { tion }\end{array}$} & \multirow{2}{*}{$\begin{array}{l}\text { Sterile males } \\
\text { released } \\
\text { (No./day) }\end{array}$} & \multirow{2}{*}{$\begin{array}{l}\text { Sterile: } \\
\text { normal } \\
\text { males }\end{array}$} & \multirow{2}{*}{$\begin{array}{c}\text { Laid } \\
\text { in } \\
\text { ovitraps } \\
\text { (No./day) }\end{array}$} & \multirow{2}{*}{$\begin{array}{l}\text { Expected } \\
\text { to be } \\
\text { sterile } \\
(\%)\end{array}$} & \multirow{2}{*}{$\begin{array}{l}\text { Actually } \\
\text { sterile } \\
(\%)\end{array}$} & \multirow{2}{*}{$\begin{array}{l}\text { Sterile } \\
\text { or } \\
\text { destroyed } \\
(\%)\end{array}$} & & \\
\hline & & & & & & & Total & Fertile \\
\hline 1 & 0 & & 228 & & 0 & 50 & & \\
\hline 2 & 8,400 & $3: 1$ & 146 & 75 & 62 & 81 & 36 & 75 \\
\hline 3 & 13,000 & $4: 1$ & 151 & 80 & 85 & 92 & 34 & 90 \\
\hline 4 & 11,000 & $12: 1$ & 47 & 92 & 82 & 91 & 79 & 96 \\
\hline 6 & 16,000 & $100: 1$ & 8 & 99 & 95 & 97.5 & 96 & 99.8 \\
\hline
\end{tabular}

generation ( 2 weeks) and calculated a daily average for this period. The release, sterility, and control data for the six generations during the test (one generation before and five generations during the release of males sterilized by thiotepa) were recorded (Table 1).

We released an average of 8,400 to 18,000 sterile males per day during the second through the sixth generation (10 June to 18 August 1969). While we could not definitely determine the ratio of sterile to normal males, we were able to make fairly accurate estimates from our information on the size of the indigenous female population. About 10 percent of the females that emerge as adults survive and lay eggs (2); therefore, the number of egg rafts laid per day multiplied by ten approximates the number of females emerging into the population each day. Since males and females occur in a ratio of about $1: \mathbb{1}$, the same number of males emerged each day. Because we could not collect all the egg rafts from the natural breeding sites, it was necessary to determine what percentage of the total egg rafts laid each day were oviposited in the ovitraps. This was done by releasing females tagged with $32 \mathrm{P}$ by exposure of the larvae to the radioactive material in water solution and determining the difference in the number of radioactive eggs laid in the ovitraps when all known breeding sites were either covered or uncovered (the test was completed after the releases had stopped). Five percent of the total number of tagged females laid their eggs in the ovitraps when the natural breeding sites were uncovered, compared with 10 percent when they were covered. Therefore, the ovitraps were 50 percent efficient and only 10 percent of the females emerging into a population survive and lay eggs. Also, the ratio of sterile to normal males during the period of releases ranged from 12 JUNE 1970
$3: 1$ in the second generation to $100: 1$ in the fifth and sixth generations.

Theoretically, the ratio of sterile to normal males should have produced from 67 percent to as much as 99 percent sterility of the females by the end of the experiment. Actually, the percentage of sterile egg rafts remained below that expected in all generations except the third. We believe that except in the second generation (at which time some fertile females that had mated prior to our release of sterile males still remained in the population) this was caused by immigration of fertilized females onto the island from fishing boats or from the mainland, because studies in large outdoor cages had demonstrated that males sterilized with thiotepa are competitive with normal males.

The C. p. quinquefasciatus females can migrate more than $3.2 \mathrm{~km}$ over land or water (3). Also, gravid females are usually present in the cabins of fishing boats that often anchor near the island at night. Moreover, if immigration of fertile females did occur it would be most noticeable in a declining population like the one we had during the final 4 weeks of our test when we obtained complete sterility of all eggs on 19 of the 28 days. Also, we invariably obtained fertile egg rafts on the days after nights when fishing boats were anchored near the island. Extensive larval surveys conducted during the last 2 weeks revealed no $C$. p. quinquefasciatus larvae in any indigenous breeding sites.

In assessing the total effect of our procedures, we must also include the effect of removal of egg rafts. Since our ovitraps collected about 50 percent of the total number of egg rafts laid each day, we used this factor to determine that the total reduction in reproductive capacity as a result of sterilization and egg removal increased from 81 percent in the second generation to 97.5 percent in the sixth generation.

During the 10 weeks that we released sterile males, the number of egg rafts collected per day dropped from a count before treatment of 228 to 8 in the ninth and tenth weeks-a reduction of 96 percent in the population. Moreover, during the sixth generation, 95 percent of the egg rafts were sterile. Thus, the actual overall reduction in fertile egg rafts was 99.4 and 99.8 percent in the last two generations.

Since the island was not completely isolated, we did not expect to eradicate the population of C. p. quinquefasciatus permanently. However, because no larvae were found during the last 2 weeks in any of the natural larval breeding sites, and because we obtained a significant suppression of the adult population (as indicated by a 96 percent decrease in egg rafts laid), we feel that we could have achieved eradication if the island had been completely isolated. Thus sterile males can be used to suppress and eradicate some species of mosquitoes under isolated conditions. However, more research is needed before such eradication can be accomplished over large areas. Migration patterns of wild and sterile males, rates of increase in populations at different times of the year, and total population densities need to be investigated (4). Obviously other population suppressants such as insecticides, reduction in breeding sources, and biological control will have to be used to decrease a total population in a large area to a level commensurate with the mass rearing capabilities (5).

R. S. Patterson, D. E. Weidhaas H. R. Ford, C. S. LOFGREN

United States Department of

Agriculture, Agricultural Research Service, Entomology Research Division, Gainesville, Florida 32601 


\section{References and Notes}

1. R. S. Patterson, H. R. Ford, C. S. Lofgren, D. E. Weidhaas, Mosquito News 30(1), 21 (1970)

2. R. S. Patterson, unpublished data.

3. E. M. Fussell, Mosquito News 24, 422 (1964); A. W. Linquist, T. Ikeshoji, B. Grab, B. De . World Health Organ. Buti. 36, 21 (1967).

4. More comprehensive data on rates of increase More comprehensione dita on and population dill will be published elsewhere. These data indicale that more than 90 percent sterility was of this mosquito population was exceeded.

5. Rearing and sterilization of mosquitoes in this experiment required about 6 man-hours per day. The $C . p$. quinquefasciatus is easy to rea and we foresee no difficulty in producing very We thank Dr. B. Smitte ror tech

6. We thank Dr. B. Smittle for technical assistance in the radioactive tagging study, Mr. M. Boston for supervising the rearing of the mosquitoes, and Dr. G. B. White [Nature 210, 1372 (1966)] for suggesting the technique of sterilizing pupae with thiotepa.

23 January 1970; revised 13 March 1970 